\title{
Landfill Gas Enrichment Impact at Net Caloric Value
}

\author{
Peter Durcansky ${ }^{1, *}$, Jozef Jandacka ${ }^{1}$, and Maria Michalkova ${ }^{2}$ \\ ${ }^{1}$ University of Žilina, Faculty of Mechanical Engineering, Department of Power Engineering, \\ Univerzitna 1, 01026 Žilina, Slovakia \\ ${ }^{2}$ University of Žilina, Faculty of Mechanical Engineering, Department of applied mathematics, \\ Univerzitna 1, 01026 Žilina, Slovakia
}

\begin{abstract}
Rising use of renewable energy sources has brought many new challenges and use of many unusual energy resources. These resources are often of lower quality, a by-product or simple waste. Landfill gas is one of resources with lower quality and unwanted elements, as sulphur derivatives. After chemical or another treatment, the gas can be used in any burning facility. This article presents numerical model, which deals with simulation of enrichment process for landfill gas and subsequent use in heat source, with simple gas burner. The final gas is simulated as gas mixture, with different components portions.
\end{abstract}

\section{Landfill gas}

All substances and objects that we cannot or do not want to use for economic reasons can be considered waste. According to the Waste Act, waste is a thing that arose during human activity that the owner wants to get rid of [1]. Waste is generated in every human activity, in the production and consumer spheres. Their origin and accumulation represents a significant impact on the environment. Waste contains substances that often endanger virtually all components of the environment, water, air and soil quality [2]. They penetrate plants and endanger the health and life of animals and the human population through the food chain. All waste generated in nature subsequently has a customer. Man-made waste is becoming an increasing burden on the environment compared to the natural cycle. There is almost no customer for the waste generated in this way who would be able to further process and use this waste. Unlike natural waste, man-made waste cannot cope with nature on its own.

Landfill gas is formed in waste storage places, mostly for long time in duration of months to years [3]. In proportion to volume, it has a significantly lower calorific value than natural gas, propane and butane, but twice as large as hydrogen. With a density of $1.2 \mathrm{~kg} / \mathrm{m}^{3}$ it is slightly lighter than air, so that flowing landfill gas cannot accumulate on the floor [4]. Conversely, when climbing mixes very quickly with air, reducing the risk of fire

\footnotetext{
*Corresponding author: peter.durcansky@,fstroj.uniza.sk
} 
or explosion. His combustion produces harmless products: water vapor and carbon dioxide [5].

In cases where production is so low or gas quality is so poor that it is impossible existing production is meaningfully used, the gas, as a waste, is only disposed of. As the most effective way at present seems to be the use of biofilters. This way is in filtering landfill gas through the layer of compost in which it is exposed methanotrophs and methylotrophes effectively breaks down methane and some trace elements. Of course, it makes more sense, if it is only a little possible and effective, produced to use landfill gas [6]. Compared to reactor biogas, landfill gas is usually lower sulfane content, they are bound to iron ions during methanogenesis, but mostly also higher content of carbon dioxide and trace components at the expense of methane. This results in worse properties of the gas in terms of its use, especially the decrease in calorific value and increase in content undesirable impurities.

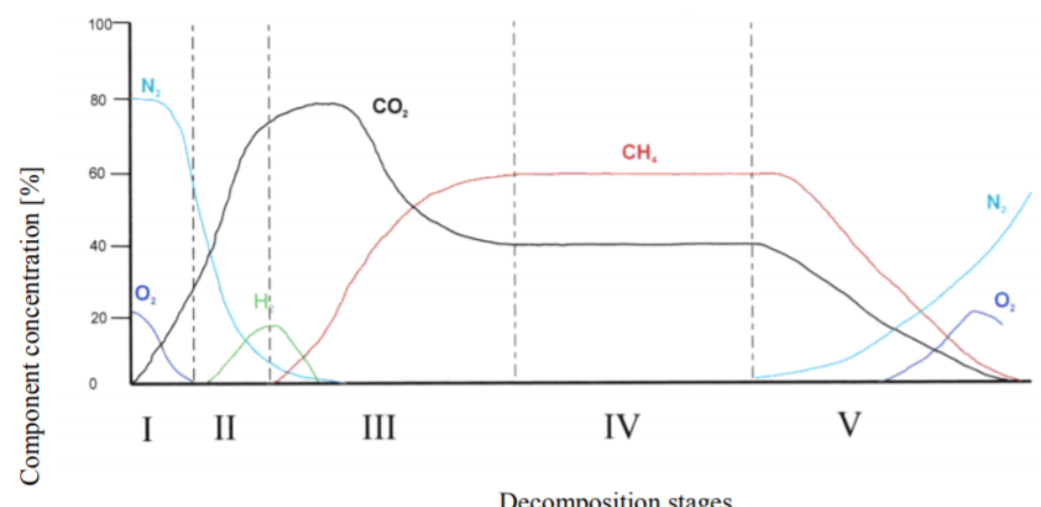

Fig. 1. Landfill gas components (source: Landfill gas energy technologies, Krakow, 2010).

Often the gas must be treated before application, which is, of course, negatively reflected in the economic evaluation of its use. The composition depends from the composition of the organic fractions in the waste. In the waste approximately $30 \%$ of methane is produced, which is very interesting in the energy use. Landfill gases differ mainly by the variability of the $\mathrm{CH}_{4}$ to $\mathrm{CO}_{2}$ ratio, not only between different landfills, but also at one landfill at different times. They also differ the type and amount of trace elements. Of the trace components, oxygen, sulfane, argon, hydrogen halides, nitrous oxide, ammonia, hydrogen, organic substances are important and organochlorine and silica compounds. The content of trace components is due to the amount of methane and oxide carbon dioxide negligible, but their level should be monitored for their negative effects on the environment as well as for equipment used in the disposal or further use of landfill gas [6]. Many of Landfill gas trace components are toxic, aggressive, and often very dangerous. Mostly landfill gases carry hazardous toxic chemicals contained in waste as volatile organic compounds compounds. Some research shows that landfill gas can even contaminate groundwater with volatile organic compounds. Our approach is to study low quality landfill gas enriched with energy dense gases, for example propane or butane.

\section{Simulation method}

Properties of landfill gas differ in many cases. The efficiency of the biogas plant operation depends on a stable supply of a suitable input raw material. In practice, manure and slurry from animal production are most often used, less waste from plant production. It is ideal to 
place a biogas plant in the area of an agricultural cooperative with cattle breeding or in its vicinity. However, the input substrate should not contain antibiotics used in animal husbandry, which kill methanogenic bacteria and inhibit biogas production. Biowaste from households, restaurants or school canteens is a suitable addition to the raw material base for a biogas plant. Mowed grass, leaves, other biological waste from animal and plant agricultural production and unused corn silage are also suitable.

The ratio of carbon to nitrogen in the blended feedstock should be in the range of 20: 1 to 40: 1 [7]. Too high a proportion of carbonaceous substances reduces the efficiency of the fermentation process and biogas production. Too high a proportion of nitrogenous substances causes increased formation of ammonia $\left(\mathrm{NH}_{4}\right)$ and odor of the biogas plant. Therefore, the composition of the materials from which the raw material entering the fermentation tank is mixed is important [8]. Carbon-rich substances are straw, grass, wood waste and dried vegetable waste. Raw materials rich in protein (waste from dairy and meat production) are in turn rich in nitrogen.

The dry matter content of the input raw materials should not fall below $3 \%$, as the fermentation would cease to be energy efficient - the biogas plant would consume more energy for its operation than the usable energy value of the produced biogas. The environment in the fermenter should be neutral or very slightly alkaline ( $\mathrm{pH}$ value 7 7.8) [9].

Depending on the consistency of the feedstock, the fermentation can be wet (the feed substrate has a dry matter content of 4-12\%) or dry (the dry matter content of the feed substrate is $20-50 \%$ ) [10]. These parameters can affect the landfill gas properties, where the final product can have lower quality as expected [11]. There we assume to enrich the gas and simulate the burning process. To simulate burning process of enriched landfill gas, we have used the Matlab software tool. The Simulink works with blocks, interconnected, with defined parameters, as for example in Figure 2.
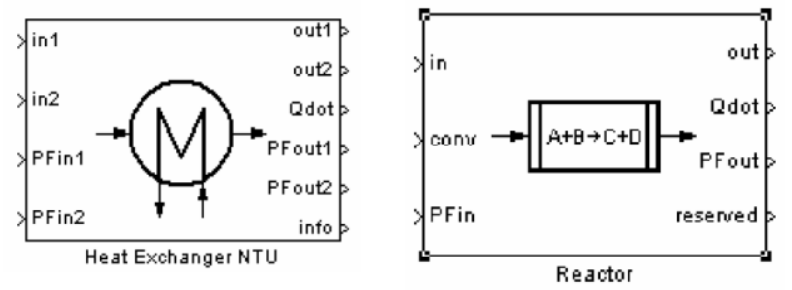

Fig. 2. Two basic parts of proposed Matlab simulation.

The simulation was performed using Thermolib library in Matlab environment. Thermolib assumes ideal liquid and gas mixtures. Therefore, the properties of mixtures are calculated from the properties of the pure substances by simple summation. One key component of Thermolib is the equilibrium reactor. It calculates the chemical equilibrium for a given initial composition and temperature at a given pressure. The thermodynamic equilibrium is defined by the minimum of the Gibbs free energy. It is assumed that all products and reactants are in gaseous phase [12]. All concentrations used, are the overall concentrations of the compounds. If temperature is greater than critical temperature, it is assumed that there is only vapour phase. Saturation pressure has no meaning in this state and is simple extrapolation of the Antoine formula beyond the critical temperature [13]. Due to the fact, that we assumed direct gas flow from landfill, the temperature was considered to be $20^{\circ} \mathrm{C}$ and so played no role [14]. After calculating the mixture, caloric value was estimated. Calculation continued with gas burning and flue gases heated heat exchanger coupled to the burner, as is shown in next figure. 


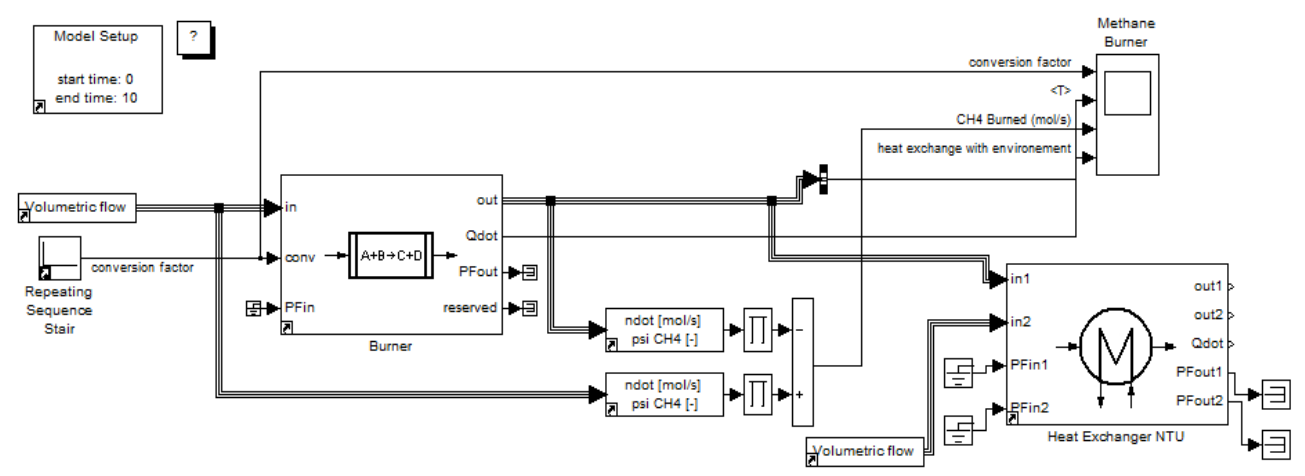

Fig. 3. Simplified numerical model in Matlab.

The change in final mixture properties resulted in change of gas caloric value, as is shown in next figure.

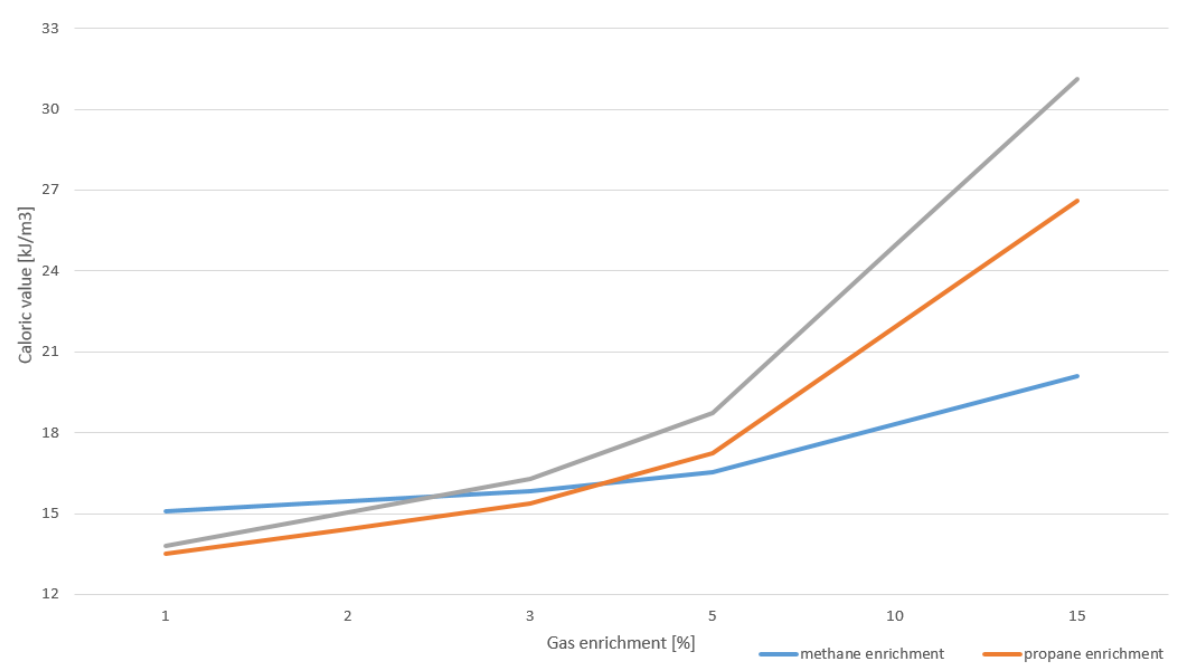

Fig. 4. Caloric value change for different enrichment.

\section{Conclusions}

Landfill gas use is rising, as the subsidiary of renewable resources is rising. This gas has in many cases not satisfying properties, mainly the caloric value. Also the presence of unwanted elements, as sulphur, ammonia and other, make it difficult to use this type of resource [15]. This simulation focused on direct burning of this gas in a gas burner, where the gas was enriched by simple methane, or petroleum gases. The caloric value was computed and simulated in Matlab, using Thermolib library. The different enrichment state showed increment of caloric value. However, the gas was considered to have constant properties, which has not to be true in real conditions, where the landfill gas composition changes over the time. 
Acknowledgements: Work on article has been financially supported by the project VEGA-1/0738 / 18 „Optimization of energy inputs for the rapid generation of natural gas and bio methane hydrates for the accumulation of high potential primary energy ", and "Influence of combustion conditions on production of solid pollutants in small heat sources", VEGA 1/0479/19. The project is published within "Research and development of waste-free technology for decomposition and selection of undesirable components from process gas generated by gasification equipment" APVV-17-0311.

\section{References}

1. A. Demirbas, Energy Conversion and Management, 51, 7 (2010)

2. P. Geffert, J. Víglaský, N. Langová, Opportunities of Landfill Gas Utilization. Život. Prostr., 40, 3, 148 - 150 (2006)

3. T. Brestovič, M. Carnogurska, M. Prihoda, P. Lukac, M. Lázár, N. Jasminská, R. Dobáková, Diagnostics of hydrogen-containing mixture compression by a two-stage piston compressor with cooling demand prediction. Appl. Sci. 8, 625 (2018)

4. F. Világi, B. Knížat, M. Mlkvik, F. Urban, R. Olšiak, P. Mlynár, Mathematical model of steady flow in a helium loop. Mechanics \& Industry, 20, $704-712$ (2019)

5. V. Foltin, J. Rajzinger, M. Juriga, Š. Gužela, Nové zdroje zemného plynu: bridlicový plyn a zemný plyn viazaný v hydrátoch, SSTP, Bratislava (2013)

6. R. Nosek, M. Holubčík, Š. Papučík, Emission controls using different temperatures of combustion air, The scientific world journal, 2014 (2014)

7. J. Kňourek, R. Matas, O. Prokeš, D. Tenkrát, Numerical simulations of natural gas flow in pipe system with flowmeters. EPJ Web of Conferences (2013)

8. M. Patsch, A. Caja, Analysis of long-time operation of micro-cogeneration unit with fuel cell, Conference: 9th International Conference On Experimental Fluid Mechanics, EPJ Web Of Conferences, 92, Article Number: 02061 (2014)

9. L. J. Orman, N. Radek, A. Kapjor, Surface Treatment Technologies for Boiling Heat Transfer augmentation, Terotechnology, 2017, Materials Research Proceedings, 216219, 5 (2018)

10. B. Skocilasova, J. Skocilas, Determination Of Pressure Drop Coefficient by CFD Simulation. Proc. of AIP Conference, vol. 1608, pp. 206-210 (2014)

11. P. Nemec, A. Caja, R. Lenhard, Analysis of heat transfer limitation of wick heat pipe, International Conference on Experimental Fluid Mechanics (2009)

12. R. Nosek, M. Holubcik, Energy properties of air dry firewood, Acta Facultitas Xylologiae Zvolen, 58, 1, 105-112, doi: 10.17423/afx.2016.58.1.12 (2016)

13. M. Holubcik, E. Jachniak, H. Smatanova, Differences between Pellets from Biomass Made in Manufactory and in Domestic Conditions, AIP Conference Proceedings, 1608, 48-53 (2014)

14. J. Najser, V. Peer, M. Vantuch, Biomass Gasification for Liquid Fuel Production, 19th International Conference on Application of Experimental and Numerical Methods In Fluid Mechanics And Energetics (2014)

15. M. Vantuch, K. Kaduchova, R. Lenhard, The Impact of Municipal Waste Combustion in Small Heat Sources, 20th International Scientific Conference On Application Of Experimental And Numerical Methods In Fluid Mechanics And Energy (2016) 